\title{
HARMONIZATION OF GOODWILL REPORTING PRACTICE IN THE CONSOLIDATED FINANCIAL STATEMENTS OF ROMANIAN GROUPS
}

\author{
Carmen-Alexandra Baltariu ${ }^{1}$ \\ Andreea Cirstea ${ }^{2}$
}

\begin{abstract}
The purpose of this paper is to analyze the current state of consolidated reporting practice harmonization concerning the extant methods for evaluating and reporting goodwill in the consolidated financial statements of Romanian groups. In order to attain our purpose we selected financial and nonfinancial Romanian groups that were listed in the Bucharest Stock Exchange and we analyzed, first in a qualitative manner, for a period of five years starting 2007, the notes to their consolidated financial statements with the design to establish exactly which of the methods stated in the International Financial Reporting Standards were being used for evaluating and reporting goodwill. The quantitative analysis, based on which certain conclusions about the current state of material harmonization concerning the practice of evaluating and reporting goodwill could be extracted, was performed by using the Herfindahl Index. The results obtained by calculating the Herfindahl Index indicate that throughout the entire period taken into account the value of the Index is constant and equal to 1, meaning that with respect to goodwill reporting practice, the groups considered make use of the same method, the purchase goodwill approach. Based on the results, our conclusion is that from the point of view of goodwill reporting practice, the groups analyzed are fully harmonized.
\end{abstract}

Keywords: material accounting harmonization, consolidated financial statements, IFRSs, goodwill reporting practice

JEL codes: M40, M41, M48

\section{Introduction}

Nowadays, more than ever, the effort to improve the international accounting system through a set of globally accepted and implemented financial reporting standards is considered a topic issue. The main reason for this is the extensively discussed possibility by the international forums according to which the international accounting system and the extant accounting regulations represent one of the factors, if not the most important factor that instigated, or at least led to the exacerbation of the economic and financial crisis in 2007. (Ojo, 2010)

This paper approaches the international accounting system domain by proposing a special focus on the material accounting harmonization process regarding the consolidated financial reporting practice of goodwill in Romania. The central theme of the paper is developed in a structure consisting of three parts. The first part includes a brief overview of the extensive literature on accounting harmonization process in order to develop a perspective on the current state of knowledge of the topic addressed, but also for a better understanding of key concepts that are operating in this field of study. The key concepts are also summarized in the first part of this work. Our study is completed with an empirical analysis over the degree of harmonization with respect to consolidated financial reporting practice, more specifically with respect to the methods used for evaluating and reporting the goodwill in the consolidated financial statements, for a period of 5 years, 2007, 2008, 2009, 2010 and 2011. The analysis was performed by measuring the degree of material accounting harmonization by using the Herfindahl Index. Following the empirical analysis we were able to draw certain conclusions presented in the last section of this paper.

\footnotetext{
1 “Babeş-Bolyai” University of Cluj-Napoca, Romania,e-mail: alexy_b2005@yahoo.com

2 "Babeş-Bolyai”" University of Cluj-Napoca, Romania,e-mail: andreseverin@yahoo.com
} 


\section{Literature Review}

The existing body of research papers regarding the subject of accounting harmonization process includes studies that address this issue through a theoretical viewpoint, by analyzing the accounting systems and/ or the accounting regulations, approaching thus the formal accounting harmonization (Standish, 2003; Yüksel et al., 2008; Wüstemann and Wüstemann, 2010), or by making a review of the studies published in this research field (Feleagă et al., 2009). Other studies approach the subject of accounting harmonization by analyzing the factors that have contributed the most to the process of formal accounting harmonization by influencing it' s development (Judge et al., 2011). The subject of accounting harmonization process has also been developed through research papers in which the analysis is based on the actual measurement of formal accounting harmonization. This body of research literature can be distinguished taking into account the research methods used in the analysis. The category includes studies developed on the basis of correlation coefficients, respectively Spearman Rank Correlation Coefficient (Fontes et al., 2005) and Pearson Correlation Coefficient (Ding et al., 2007), or on the basis of association coefficients - Jaccard's Coefficients (Fontes et al., 2005), or studies in which the analysis was developed by using other mathematical methods, respectively the fuzzy clustering analysis (Qu and Zhang, 2010), or disclosure indexes, for example Cooke disclosure index (Tiron-Tudor, 2009). The subject of accounting harmonization process can also be approached through the material point of view, by trying, making use of various methods, to quantify the degree in which the financial reporting practice has been harmonized. A comprehensive review of the body of research literature written on the subject mentioned above can be found in Mustață and Matiş, 2010. According to many researchers opinion, the corner stone of the material accounting harmonization theme can be found in the study of van der Tas, 1988. In this study, van der Tas describes as measurement method of financial reporting practice harmonization the Herfindahl index, which measures the degree of concentration at a national level, in the case of taking into consideration a single element/ item of comparison (without taking multiple reporting into account). In the same study, van der Tas also presents new forms of the aforementioned method, developed based on Herfindahl index: the $\mathrm{C}$ index, which takes into consideration multiple reporting and the I index, which measures international material harmonization. (van der Tas, 1988: 159)

\section{Conceptual Framework}

\section{Working concepts}

After consulting the research literature, we appreciate that the concept of accounting harmonization designates the decrease in the degree of international accounting diversity and the growth of accounting uniformity (Tay and Parker 1990: 73; Mustață 2008: 60-93). The concept of accounting harmonization also refers to the degree of compatibility and/ or comparability between a national and an international accounting referential, in the same time implying the orientation of the national accounting referential towards the international financial reporting framework by assuming greater efforts to reduce disparities (Mustață 2008: 6093).

The concept of accounting harmonization was developed in the research literature by van der Tas, 1988. Thus, two other new concepts were created, respectively: formal (de jure) accounting harmonization and material (de facto) accounting harmonization. The clear distinction made by the author mentioned above between formal (de jure) accounting harmonization and material (de facto) accounting harmonization can be found in other research papers too (Van der Tas 1992: 470; Parker 1996: 317; Canibano and Mora 2000: 351353). According to the literature references mentioned above, the concept of formal accounting harmonization refers to the degree of comparability between regulations and accounting standards, whereas material accounting harmonization takes the meaning of the degree to which accounting rules and methods provided in the regulations and/ or standards are observed and enforced by companies in their financial reporting practices. In general, in the research literature the material accounting harmonization is seen as a process that occurs as a consequence of formal accounting harmonization. This fact can be considered a proof that in an accounting system the rules and standards are the first to be harmonized, followed by the accounting practice. 
Regarding the design and the presentation of consolidated financial statements, we found analyzed in the research literature four main theories: the proprietary theory, the parent company theory, the parent company extended theory and the entity theory. (Abad et al., 2000: 156-176; Baluch et al., 2010: 1-12; Dolinar, 2002; Grossi and Gardini, 2012: 1-28; Müller, 2010: 56-63; Săcărin, 2008: 30-39) These four theories were developed in time, encompassing various elements found in accounting practice. Taking into account the proprietary theory, our analysis made us conclude that the consolidated subsidiary was considered just an extension of the parent company, the consolidated financial statements were designed only for the use of the parent company shareholders and the minority interests were not in any way recognized or reported in the consolidated financial statements. Starting from this theory, through a natural evolution of principles, theories and concepts in accounting, another step was taken, some of the proprietary theory elements were replaced and the other consolidation theories were developed. The last one of them - the entity theory - differs significantly from the other three theories mentioned above. Under the entity theory, a subsidiary is considered as a separate entity from its owners, but also from its parent company, the consolidated financial statements are prepared for all parties who have interests in the entity to be consolidated (both the parent company, as well as minority interests) and minority interests are recognized and reported as part of the equity in the consolidated financial statements.

In order to have a more clear and concise vision of the differences, but also of the common elements that link the four theories of consolidation, but without trying to analyze this issue in an exhaustive manner, we developed a short comparison in (table no. 1). The elements of the comparative analysis are the following: use of the consolidated financial statements, view over the consolidated entity, recognition of minority interests, presentation of minority interests in the consolidated financial statements, treatment of investment in a subsidiary, presentation of consolidated net income in the consolidated financial statements, treatment of intercompanies transactions and treatment of goodwill resulted after the purchase of a subsidiary.

Table no. 1

Consolidation theories, a comparative approach

\begin{tabular}{|c|c|c|c|c|}
\hline $\begin{array}{l}\text { Element of } \\
\text { comparison }\end{array}$ & Proprietary theory & $\begin{array}{c}\text { Parent company } \\
\text { theory }\end{array}$ & $\begin{array}{l}\text { Parent company } \\
\text { extension theory }\end{array}$ & Entity theory \\
\hline $\begin{array}{l}\text { Use of } \\
\text { consolidated } \\
\text { financial } \\
\text { statements }\end{array}$ & $\begin{array}{l}\text { Produced only for } \\
\text { parent company } \\
\text { stockholders; } \\
\text { Represent an } \\
\text { extension of the } \\
\text { parent company } \\
\text { individual financial } \\
\text { statements }\end{array}$ & $\begin{array}{l}\text { Generated only for } \\
\text { parent company } \\
\text { stockholders; } \\
\text { Represent an } \\
\text { extension of the } \\
\text { parent company } \\
\text { individual financial } \\
\text { statements }\end{array}$ & $\begin{array}{l}\text { Produced only for } \\
\text { parent company } \\
\text { stockholders; } \\
\text { Represent an extension } \\
\text { of the parent company } \\
\text { individual financial } \\
\text { statements }\end{array}$ & $\begin{array}{l}\text { Intended for all parties } \\
\text { who have an interest in } \\
\text { the consolidated entity }\end{array}$ \\
\hline $\begin{array}{l}\text { View over the } \\
\text { consolidated } \\
\text { entity }\end{array}$ & $\begin{array}{l}\text { The consolidated } \\
\text { entity is an } \\
\text { extension of the } \\
\text { parent and is under } \\
\text { the control of the } \\
\text { parent company; } \\
\text { The assets and } \\
\text { liabilities of the } \\
\text { subsidiary are } \\
\text { considered owned } \\
\text { by the parent }\end{array}$ & $\begin{array}{l}\text { The consolidated } \\
\text { entity is not an } \\
\text { extension of the } \\
\text { parent company, but } \\
\text { is under the control of } \\
\text { the parent; } \\
\text { The assets and } \\
\text { liabilities of the } \\
\text { subsidiary are not } \\
\text { considered owned by } \\
\text { the parent, but } \\
\text { controlled by the } \\
\text { parent company }\end{array}$ & $\begin{array}{l}\text { The consolidated entity } \\
\text { is not an extension of } \\
\text { the parent company, } \\
\text { but is under the control } \\
\text { of the parent; } \\
\text { The assets and } \\
\text { liabilities of the } \\
\text { subsidiary are not } \\
\text { considered owned by } \\
\text { the parent, but } \\
\text { controlled by the parent } \\
\text { company }\end{array}$ & $\begin{array}{l}\text { The consolidated entity } \\
\text { is view as being } \\
\text { separate from the parent } \\
\text { company and from the } \\
\text { owners of the parent }\end{array}$ \\
\hline
\end{tabular}




\begin{tabular}{|c|c|c|c|c|}
\hline $\begin{array}{l}\text { Recognition of } \\
\text { Minority Interests }\end{array}$ & NO recognition & Recognition & Recognition & Recognition \\
\hline $\begin{array}{l}\text { Presentation of } \\
\text { Minority Interests } \\
\text { in the } \\
\text { consolidated } \\
\text { financial } \\
\text { statements }\end{array}$ & NO report & $\begin{array}{l}\text { Reported as a liability } \\
\text { (from the viewpoint } \\
\text { of the parent); } \\
\text { The Minority } \\
\text { Interests are valued at } \\
\text { their pro rata share of } \\
\text { the net book values of } \\
\text { the subsidiary assets } \\
\text { and liabilities; } \\
\text { The value does not } \\
\text { include the Minority } \\
\text { Interests pro rata share } \\
\text { of the difference } \\
\text { between the fair } \\
\text { market value and the } \\
\text { net book value of the } \\
\text { subsidiary net assets }\end{array}$ & $\begin{array}{l}\text { Reported in a special } \\
\text { section between the } \\
\text { liabilities and the } \\
\text { equity; } \\
\text { The Minority Interests } \\
\text { are valued at their pro } \\
\text { rata share of the fair } \\
\text { market values of the } \\
\text { subsidiary assets and } \\
\text { liabilities; }\end{array}$ & $\begin{array}{l}\text { Reported as part of the } \\
\text { stockholders equity (the } \\
\text { same as the controlling } \\
\text { interest); } \\
\text { The Minority Interests } \\
\text { are valued at their pro } \\
\text { rata share of the fair } \\
\text { market values of the } \\
\text { subsidiary assets and } \\
\text { liabilities; }\end{array}$ \\
\hline $\begin{array}{l}\text { Investment in a } \\
\text { subsidiary }\end{array}$ & $\begin{array}{l}\text { The assets and } \\
\text { liabilities are valued } \\
\text { at the parent } \\
\text { company pro rata } \\
\text { share of the book } \\
\text { values plus the } \\
\text { excess of cost over } \\
\text { the book values of } \\
\text { subsidiary assets } \\
\text { and liabilities (the } \\
\text { purchase } \\
\text { differential) }\end{array}$ & $\begin{array}{l}\text { The assets and } \\
\text { liabilities are valued at } \\
100 \% \text { of the book } \\
\text { values plus the parent } \\
\text { company pro rata } \\
\text { share of the purchase } \\
\text { differential }\end{array}$ & $\begin{array}{l}\text { The assets and } \\
\text { liabilities are taken into } \\
\text { consideration } 100 \% \\
\text { and are valued at fair } \\
\text { market values }\end{array}$ & $\begin{array}{l}\text { The assets and } \\
\text { liabilities are taken into } \\
\text { consideration } 100 \% \\
\text { and are valued at fair } \\
\text { market values }\end{array}$ \\
\hline $\begin{array}{l}\text { Consolidated net } \\
\text { income }\end{array}$ & $\begin{array}{l}\text { The parent } \\
\text { company includes } \\
\text { only its pro rata } \\
\text { share of subsidiary } \\
\text { income and } \\
\text { eliminates } 100 \% \text { of } \\
\text { unrealized gains and } \\
\text { losses }\end{array}$ & $\begin{array}{l}\text { The parent company } \\
\text { includes only its pro } \\
\text { rata share of } \\
\text { subsidiary income } \\
\text { and eliminates } 100 \% \\
\text { of unrealized gains } \\
\text { and losses }\end{array}$ & $\begin{array}{l}\text { The parent company } \\
\text { includes only its pro } \\
\text { rata share of subsidiary } \\
\text { income and eliminates } \\
100 \% \text { of unrealized } \\
\text { gains and losses }\end{array}$ & $\begin{array}{l}\text { All of the consolidated } \\
\text { net income is included } \\
\text { (the parent company } \\
\text { pro rata share and the } \\
\text { Minority Interests pro } \\
\text { rata share) }\end{array}$ \\
\hline $\begin{array}{l}\text { Inter-companies } \\
\text { gains and losses }\end{array}$ & $\begin{array}{l}\text { The parent } \\
\text { company eliminates } \\
\text { only its pro rata } \\
\text { share of both } \\
\text { upstream and } \\
\text { downstream } \\
\text { transactions (that } \\
\text { took place between } \\
\text { the group } \\
\text { companies) }\end{array}$ & $\begin{array}{l}\text { The parent company } \\
\text { eliminates its pro rata } \\
\text { share, or } 100 \% \text { of } \\
\text { both upstream and } \\
\text { downstream } \\
\text { transactions }\end{array}$ & $\begin{array}{l}\text { The parent company } \\
\text { eliminates } 100 \% \text { of } \\
\text { both upstream and } \\
\text { downstream } \\
\text { transactions }\end{array}$ & $\begin{array}{l}\text { The parent company } \\
\text { eliminates } 100 \% \text { of } \\
\text { both upstream and } \\
\text { downstream } \\
\text { transactions }\end{array}$ \\
\hline $\begin{array}{l}\text { Goodwill } \\
\text { (following the } \\
\text { purchase of a } \\
\text { subsidiary) }\end{array}$ & $\begin{array}{l}\text { Established as the } \\
\text { difference between } \\
\text { the purchase price } \\
\text { and the fair market } \\
\text { value of the } \\
\text { subsidiary (its net }\end{array}$ & $\begin{array}{l}\text { Established as the } \\
\text { difference between } \\
\text { the purchase price and } \\
\text { the fair market value } \\
\text { of the subsidiary (its } \\
\text { net asset); }\end{array}$ & $\begin{array}{l}\text { Established as the } \\
\text { difference between the } \\
\text { purchase price and the } \\
\text { fair market value of the } \\
\text { subsidiary (its net } \\
\text { assets); }\end{array}$ & $\begin{array}{l}\text { Established by using } \\
\text { two methods: } \\
\text { 1.the extrapolation of } \\
\text { the value of purchased } \\
\text { goodwill } \\
\text { 2.the decrease of the }\end{array}$ \\
\hline
\end{tabular}




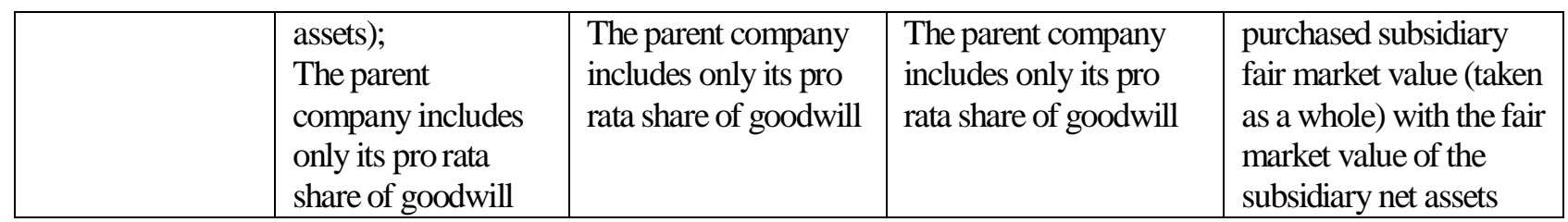

Source: Author's analysis

\section{The international regulators approach concerning the four consolidation theories}

This section will refer only to IFRSs and the Seventh Directive, excluding from the analysis U.S. GAAP regulations as the case study that will be presented next focuses only on Romanian groups and Romania's accounting system has been shaped and influenced mostly by the two sets of international accounting regulations mentioned above.

With respect to the International Financial Reporting Standards - IFRS - the influences of each of the four theories mentioned above can be observed as being embodied in various elements. The property theory is represented in the IFRSs through IAS 31, which states that for elaborating the consolidated financial statements in the case of joint ventures the method to be used is the proportional consolidation method. The influence of the parent company theory led to the preservation of the option regarding the evaluation and the reporting only of the parent company corresponding percentage of goodwill, without taking into consideration the percentage of goodwill belonging to the minority interests. This option was still used even after reviewing IFRS 3 and IAS 27 in 2008, which brought the international financial reporting standards closer to the entity theory (RSM International, 2011; Müller, 2010: 62). Under this option, the goodwill is presented in the consolidated balance sheet as an asset at a value equal to the amount, or price paid by the purchasing entity, considered at fair value, minus the net assets of the acquired entity, considered also at fair value. This approach or treatment method of goodwill (the purchased goodwill approach) is based on the cost, and on the idea that the acquisition of an entity should be treated as an asset purchase. Also, the requirement to disclose earnings attributable to the majority interests (meaning the parent company) per share is a consequence of the influence of the parent company theory on IFRSs. Through it all, it can be observed that the IFRS requirements reflect mostly the vision of the entity theory, and more so after the review of IFRS 3 and IAS 27. Thus, in terms of investment in a subsidiary, all assets and liabilities are $100 \%$ taken into consideration in the consolidated balance sheet, being evaluated at a fair market value; in the consolidated profit and loss account the total result of the group is being reported; in the consolidated balance sheet, the minority interests are being presented in the equity section; and also the total amount of goodwill (the parent company share, as well as the minority interests incumbent value) is being taken into consideration and evaluated (the full goodwill approach). The recognition method used in this case is based on the price paid by the acquiring company for purchasing the net assets of the subsidiary, which becomes the basis for assessing the entire company acquired. (RSM International, 2011)

Regarding the European Commission Seventh Directive, our analysis showed us that this regulatory framework also received influences from the property theory materialized in the proportional consolidation method used in the case of a joint venture. The entity theory has made its mark with respect to the presentation of minority interests, which is being done as in the case of IFRSs, while the parent company theory influenced especially the assessment of assets and liabilities resulted from an investment in a subsidiary, but also the evaluation of minority interests and goodwill (table no. 1).

\section{Legal framework in Romania}

Romania became a member state of the European Union in 2007. By that time, however, the Romanian accounting environment has been gone through major changes that led to the formal harmonization, both in terms of accounting regulations issued by the European Commission, namely the Fourth Directive concerning the elaboration of individual financial statements and the Seventh Directive concerning the elaboration of consolidated financial statements, as well as in terms of international financial reporting standards developed by the IASB. The most representative legal act by which the Romanian accounting legislation completed its formal harmonization with the European Community acquis is named OMFP no. 1752/2005, for approval of conformation of accounting regulations with the European Directives applicable as 
of $1^{\text {st }}$ of January 2006 to all legal persons stated in the Accounting Law no. 82/1991. This law contained rules concerning accounts consolidation. OMFP no. 1752/2005 has been replaced by OMFP no. 3055/2009 for approval of conformation of accounting regulations with the European Directives, with effect from $1^{\text {st }}$ of January 2010. This legal act did not bring significant changes concerning the rules on drawing up the consolidated accounts and the consolidated financial statements. Meanwhile, the formal harmonization process with the international financial reporting standards taking place in the European Union led to the adoption of IFRSs through the so called endorsement mechanism (Müller, 2010: 85). To this end the European Parliament and the EU Council issued the EC Regulation no. 1606/2002 for the application of international accounting standards, which required all companies admitted/ listed on the European markets to prepare consolidated financial statements in conformity with the international accounting standards IAS, starting from the financial year of 2005, and also the EC Regulation no. 1725/2003 for the adoption of certain international accounting standards, which accepts the application of existing IFRSs, issued before 2002. This last regulation was later replaced by EC Regulation no. 1126/2008 for the adoption of certain international accounting standards. The formal harmonization process with the international accounting standards occurring at a European level had its consequences in Romania's accounting legislation also. Thus, some changes and additions were made to OMFP no. 1752/2005, through OMFP no. 1121/2006 for the implementation of IFRSs in Romanian public interest entities consolidated financial statements as of year 2007, but also through OMFP no. 2374/2007 issued for allowing public entities other than listed companies, credit institutions and non-banking financial institutions, insurance companies, insurance-reinsurance companies and reinsurance companies, pension fund companies, investment services companies, financial investment management companies and collective investment schemes to prepare consolidated financial statements according to national accounting regulations consistent with the Seventh Directive, or to comply with IFRSs. (Müller, 2010: 93)

\section{Research Methodology}

The central theme of this article is restricted to the existing material (de facto) accounting harmonization within the consolidated financial situations of group companies in Romania. Our study approaches de facto accounting harmonization of financial reporting practices with respect to the method applied by the parent company regarding the evaluation and reporting of goodwill in the consolidated financial statements. As we mentioned in the previous section, in the international financial reporting standards two methods are to be considered with respect to this subject: the purchase goodwill approach (method 1) and the full goodwill approach (method 2).

This paper is an empirical research that addresses from a comparative perspective the degree of material accounting harmonization taking into account the Herfindahl Index. As we mentioned above, the Herfindahl Index, described by van der Tas, 1988: 159, is a measurement method of financial reporting practice harmonization, focusing on the degree of concentration at a national level, while considering a single element/ item of comparison (without taking multiple reporting into account). The formula of the Herfindahl Index is:

$$
H-\sum_{i=1}^{n} p_{i}^{2}
$$

Where:

$\mathrm{H}=$ Herfindahl Index;

$\mathrm{n}=$ number of alternative accounting methods;

$\mathrm{p}_{\mathrm{i}}=$ the relative frequency of accounting method $\mathrm{i}$.

The Herfindahl Index fluctuates between 0 (no harmony) and 1 (all companies using the same method).

The research methodology of this paper includes both qualitative and quantitative research methods, among which we can distinguish the analysis of documents, the analysis of consolidated financial statements of Romanian groups included in the study, the comparative method, the interpretative method and last but not least, the mathematical and statistical research methods, represented by the Herfindahl Index, described in the previous paragraph. 


\section{Case Study}

The groups included in our study are just a part of those that are listed in the Bucharest Stock Exchange (BSE) for the financial years of 2007, 2008, 2009, 2010 and 2011. All the groups considered were obliged to comply with the international financial reporting standards regarding their consolidated financial statements. Still, the sample did not have a constant number for the entire period analyzed, because some of the groups did not have in their notes to consolidated financial statements a section dedicated to the information concerning the treatment of goodwill. The structure of the sample is the following:

Table no. 2

Sample description

\begin{tabular}{|c|c|c|c|c|c|}
\hline GROUP TYPE & \multicolumn{5}{|c|}{ YEAR } \\
\hline & 2007 & 2008 & 2009 & 2010 & 2011 \\
\hline Non-financial groups & 2 & 3 & 3 & 3 & 5 \\
\hline Financial groups & 5 & 5 & 5 & 5 & 5 \\
\hline TOTAL & 7 & 8 & 8 & 8 & 10 \\
\hline
\end{tabular}

Source: Author's analysis

For the financial years of 2007, 2008, 2009, 2010, 2011 we analyzed the consolidated financial statements of the groups, more specific, the notes to consolidated financial statements, in order to see which of the methods dedicated to the treatment of goodwill, the purchase method (method 1), or the full goodwill method (method 2), is being used for evaluating and reporting this item. After this qualitative analysis, we used the Herfindahl Index in order to calculate the extant degree of harmonization regarding the goodwill reporting practice in the consolidated financial statements. The results are shown in (table no. 3).

Table no. 3

Results

\begin{tabular}{|c|c|c|c|c|c|}
\hline \multirow[t]{3}{*}{ YEAR/GROUP TYPE } & \multicolumn{4}{|c|}{ METHOD } & \multirow{3}{*}{$\begin{array}{c}\text { HERFINDAHL } \\
\text { INDEX } \\
\mathbf{H}=\mathbf{p}_{1}{ }^{2}+\mathbf{p}_{2}^{2}\end{array}$} \\
\hline & \multicolumn{2}{|c|}{$\begin{array}{l}\text { METHOD 1: (The purchased } \\
\text { goodwill approach) }\end{array}$} & \multicolumn{2}{|c|}{$\begin{array}{l}\text { METHOD 2: (The full goodwill } \\
\text { approach) }\end{array}$} & \\
\hline & $\begin{array}{l}\text { ABSOLUTE } \\
\text { VALUES }\end{array}$ & $\begin{array}{l}\text { RELATIVE } \\
\text { VALUES }\left(p_{1}\right)\end{array}$ & $\begin{array}{l}\text { ABSOLUTE } \\
\text { VALUES }\end{array}$ & $\begin{array}{l}\text { RELATIVE } \\
\left.\text { VALUES ( } p_{2}\right)\end{array}$ & \\
\hline 2007 & 7 & 1 & 0 & 0 & 1 \\
\hline Non-financial groups & 2 & 1 & 0 & 0 & 1 \\
\hline Financial groups & 5 & 1 & 0 & 0 & 1 \\
\hline 2008 & 8 & 1 & 0 & 0 & 1 \\
\hline Non-financial groups & 3 & 1 & 0 & 0 & 1 \\
\hline Financial groups & 5 & 1 & 0 & 0 & 1 \\
\hline 2009 & 8 & 1 & 0 & 0 & 1 \\
\hline Non-financial groups & 3 & 1 & 0 & 0 & 1 \\
\hline Financial groups & 5 & 1 & 0 & 0 & 1 \\
\hline 2010 & 8 & 1 & 0 & 0 & 1 \\
\hline Non-financial groups & 3 & 1 & 0 & 0 & 1 \\
\hline Financial groups & 5 & 1 & 0 & 0 & 1 \\
\hline 2011 & 10 & 1 & 0 & 0 & 1 \\
\hline Non-financial groups & 5 & 1 & 0 & 0 & 1 \\
\hline Financial groups & 5 & 1 & 0 & 0 & 1 \\
\hline
\end{tabular}

Source: Author's analysis 


\section{Conclusions}

The results of the study are synthesized in (table no. 2) and (table no. 3), based on which we can draw certain conclusions regarding the material harmonization of the goodwill reporting practice in the consolidated financial statements of the Romanian groups analyzed. It can be observed the fact that the number of companies presenting in their consolidated financial statements, more specifically in the notes to the consolidated financial statements, a section for describing the treatment of goodwill is not constant throughout the entire period analyzed. As such, as (table no. 2) and (table no. 3) show, the number of groups that could be taken into consideration for calculating the Herfindahl Index is also not constant. This number is increasing from a total of 7 groups in 2007, to a total of 8 groups in 2008, 2009 and 2010 and finally in 2011 we see a total of 10 groups.

In (table no. 3) we also presented the values of the Herfindahl Index (column no. 6) for each year starting 2007 and ending with 2011, comprising the entire period analyzed. We also presented in a separate manner the values of the Herfindahl Index for non-financial groups as well as for financial groups. Taken into consideration the Herfindahl formula and the fact that we have only two methods included in our analysis, $n$ takes the value of 2, so the results of the Herfindahl Index presented in column no. 6 were obtained by summing up the squared relative values calculated for the purchase goodwill approach (method 1$)-p_{l}^{2}-$ and for the full goodwill approach (method 2$)-p_{2}^{2}$. These relative values can be obtained by dividing the number of companies that make use of a certain method for evaluating and reporting goodwill with the total number of companies included in the analysis. As (table no. 3) shows, the value of the Herfindahl Index is constant throughout the entire period taken into account, being equal to 1 . The fact that the value of the Herfindahl Index is 1 proves us that regarding the method used for evaluating and reporting goodwill, the consolidated financial reporting practice of the groups included in the analysis is harmonized, all the groups using the same method: the purchased goodwill approach. What is very interesting to observe, is the fact that even if in 2008 a review of IFRS 3 and of IAS 27 took place, the full goodwill approach being thus introduced as a method which better reflects the entity theory, not even one of the Romanian groups analyzed did not make use of this new method.

Our paper makes a contribution to the extant literature on material harmonization of the consolidated financial reporting practice by examining the current state of de facto harmonization regarding the evaluation and reporting of goodwill in the consolidated financial statements of Romanian groups. Our findings suggest that the groups analyzed are fully harmonized in this respect, but the limitations of our research - the small number of groups sampled, the use of a single quantitative method for the analysis - do not allow us to draw any general conclusions. These limitations, however, are being considered as challenges that can be addressed in our future research.

\section{References}

1. Abad C., Garcia-Borbolla A., Laffarga J., Larran M., Piñero J.M., 2000. An Evaluation of the Value Relevance of Consolidated Versus Unconsolidated Accounting Information: Evidence from Quoted Spanish Firms, Journal of International Financial Management and Accounting, 11(3), pp. 156-176;

2. Baluch C., Burgess G., Cohen R., Kushi E., Tucker P. J., Volkan A., 2010. Consolidation theories and push-down accounting: achieving global convergence, Journal of Finance and Accountancy, pp. 1-12;

3. Canibano L., Mora A., (2000), Evaluating the statistical significance of de facto accounting harmonization: A study of European global players, European Accounting Review, 9(3), pp. 349-369;

4. Ding Y., Hope O. K., Jeanjean T., Stolwy H., 2007. Differences between domestic accounting standards and IAS: Measurement, determinants and implications, Journal of Accounting and Public Policy, 26(1), pp. 1-38;

5. Dolinar D., 2002. An Evaluation of the Value Relevance of Consolidated and Unconsolidated Accounting Information: Evidence from the United Kingdom, University of Ljubljana, available online at http://www.cek.ef.uni-lj.si/magister/dolinar75.pdf; 
6. Feleagă L., Feleagă N., Dragomie V. D., 2009. National standards and european accounting harmonization: twenty years of scientific literature in review, European Journal of Management, 9(2), pp. 1-12;

7. Fontes A., Rodrigues L. L., Craig R., 2005. Measuring convergence of National accounting Standards with International Financial Reporting Standards, Accounting Forum, 29(4), pp. 415-436;

8. Grossi G., Gardini S., 2012. Theories and methods of consolidation Interaction between private and public sector accounting standards within the hybrid case of Stockholm city, $7^{\text {th }}$ International Conference on Accounting, Auditing and Management in Public Sector Reforms, Milan, September 4 6, 2012, available online at www.eiasm.org/documents/abstracts/36273

9. IAS Plus, 2010. Implementation of the IAS Regulation (1606/2002) in the EU and EEA, available online at http://ec.europa.eu/internal_market/accounting/docs/ias/ias-use-of-options2010_en.pdf;

10. Judge W., Li S., Pinsker R., 2010. National Adoption of International Accounting Standards: An Institutional Perspective, Corporate Governance: An International Review, 18(3), pp.161-174;

11. Mustață R. V., 2008. Sisteme de măsurare a armonizării şi diversităţii contabile - între necesitate şi spontaneitate, Casa Cărții de Ştiință Publishing House, Cluj-Napoca;

12. Mustață R. V., Matiş D., 2010. Systems for material harmonization measurement within the changing global environment: a review, Journal of Organisational Transformation and Social Change, 7(1), pp. 47-87;

13. Müller V. O., 2010. Situațiile financiare consolidate dezvoltări şi aprofundări la nivel internațional, european si național, Cluj-Napoca, Alma Mater;

14. Ojo M., 2010. The role of IASB and Auditing Standards in the Aftermath of the 2008/2009 Financial Crisis, European Law Journal, 16:5, pp. 604-623;

15. RSM International The Worldwide Audit, Tax \& Consulting Network, 2011. The New Approach to Business Combination Introduced by the Revised IFRS 3 and the Revised IAS 27, available online at $\mathrm{http} / / / w w w . r s m f a r r e l l g r a n t s p a r k s . i e / w p-c o n t e n t / u p l o a d s / 2011 / 04 / I F R S 3-a n d-t h e-r e v i s e d-I A S-27 . p d f ;$

16. Qu X., Zhang G., 2010. Measuring the convergence of national accounting standards with international financial reporting standards: The application of fuzzy clustering analysis, The International Journal of Accounting, 45(3), pp. 334-355;

17. Săcărin M., 2008. Teoriile consolidării şi implicațiile acestora în informarea financiară, Audit Financiar, IV (10), pp. 29-39;

18. Standish P., 2003. Evaluating National Capacity for Direct Participation in International Accounting Harmonization: France as a Test Case, Abacus, 39(2), pp.186-210;

19. Tay J. S. W., Parker R. H., 1990. Measuring international harmonization and standardization, Abacus, 26(1), pp. 71-88;

20. Tiron-Tudor A., 2009. Disclosure practices concerning consolidated financial statements of Romanians groups of entities, Annals of Faculty of Economics, 1(1), pp. 600-606;

21. Van der Tas L.G., 1988. Measuring Harmonisation of Financial Reporting Practice, Accounting and Business Research, 18(70): 157-169;

22. Van der Tas, L. G., 1992. Measuring International harmonization and standardization: A comment, Abacus, 28(2), pp. 211-216;

23. Yüksel K. Y., Volkan D., Lutfiye D. D., 2008. International financial reporting standards (IFRS) and the development of financial reporting standards in Turkey, The International Journal of Accounting, 26(2), pp. 304-313;

24. Wüstemann J., Wüstemann S., 2010. Why Consistency of Accounting Standards Matters: A Contribution to the Rules-Versus-Principles Debate in Fianancial Reporting, Abacus, 46(1), pp. 1-27. 